This is an electronic reprint of the original article. This reprint may differ from the original in pagination and typographic detail.

Author(s): Mykkänen, Markus

Title: Clarifying Communication Professionals' Tasks In Contributing To Organizational Decision Making

Year: $\quad 2017$

Version:

Please cite the original version:

Mykkänen, M. (2017). Clarifying Communication Professionals' Tasks In Contributing To Organizational Decision Making. International Journal of Social Sciences and Humanities Invention, 4(5), 3460-3468. https://doi.org/10.18535/ijsshi/v4i5.01

All material supplied via JYX is protected by copyright and other intellectual property rights, and duplication or sale of all or part of any of the repository collections is not permitted, except that material may be duplicated by you for your research use or educational purposes in electronic or print form. You must obtain permission for any other use. Electronic or print copies may not be offered, whether for sale or otherwise to anyone who is not an authorised user. 


\title{
Clarifying Communication Professionals' Tasks In Contributing To Organizational Decision Making
}

\author{
Markus Mykkänen
}

Department of Language and Communication Studies, University of Jyväskylä, Finland.

\begin{abstract}
The purpose of this paper is to discuss the tasks through which communication professionals and public relations contribute to organizational decision making. In-depth interviews were conducted with Finnish public relations professionals about how they contribute to organizational decision making. The findings provide a rich picture of the tasks in relation to this. The results show that public relations professionals contribute to organizational decision-making processes by nine different tasks. Furthermore, the results indicate that during an organizational decision-making process, professionals switch from one task to another over time, and work simultaneously on several tasks. This paper offers a comprehensive representation of the various tasks through which public relations professionals contribute to organizational decision making, and provides a detailed description of the various tasks throughout the phases of a decision-making process. Based on the findings, this paper introduces a contribution model for further investigation of the topic. The model can be used as a referring tool in practice to enhance communicative processes related to organizational strategy and decision making, and in this way the model will also further the bridging function and strategic role of public relations when adapting to a changing environment.
\end{abstract}

\section{Keywords: Communication professionals, Decision making, Public Relations, Sensemaking, Tasks.}

\section{INTRODUCTION}

The value of public relations is often considered to be in facilitating how organizations negotiate and adapt to their social environment. Organizations are expected to use strategies and attend their external environment to achieve growth and survival (Pace and Faules, 1994). Public relations is expected to help organizations understand their environments (White and Mazur, 1995), enact them (Cheney, Christensen, Zorn and Ganesh, 2004), anticipate and defuse potential problems (Fawkes, 2004) and adjust and adapt to changes in the environment of the organization (Cutlip, Center and Broom, 2006). This relates to decision making within organizations and, in particular, to what extent stakeholders, the groups vital for the organizations and their existence, are taken into account or included in decision-making processes. The contribution of public relations to organizational decision making, as Dozier (1989) stated, has traditionally been embedded in the process of two-way exchange between the dominant coalition of the organization, i.e. the individuals responsible for strategy and top decisions, and the stakeholders of the organization. Later, Dozier and Broom (1995, p. 22) emphasized that the value of public relations is derived from "public relations' ability to solve problems for the organization".

In scientific and professional literature, as Van Ruler and de Lange (2003, p. 146) underlined, it has been suggested that organizations should have a specific function which aims to facilitate "direct communication and information processes to help achieve organizational goals." This strategic communication management assists the functioning of the organization, provides counselling for the management at all levels in the organization, and effectuates management decisions (PRSA, 1982). Van Ruler and de Lange (2003) argued that, in order to achieve the goals of an organization, all activities of direct communication and information processes must be included in decision-making processes.

The theoretical foundation of the role of public relations in strategic management and in the contribution to decisionmaking processes was created in 1984, when Grunig (2006) brought together several middle range theories, including the role of public relations in organizational decision making. The following Excellence study presented the value of public relations to organizations. By providing theoretical and empirical evidence, the Excellence study (Grunig 2006, p. 160) showed that "involvement in strategic management was the critical characteristic of excellent public relations". Excellent public relations requires access to the dominant coalition through representation. Without this kind of empowerment, the effect of the discipline on organizational decision making would be minimal. To be effective, public relations must act in ways that satisfy the management and that, at the same time, solve the problems at hand. This calls for bridging the interests of the stakeholders and the organization.

The focus of this paper is to discuss the tasks through which public relations professionals contribute to organizational decision making. First, the literature is brought together to clarify the environment in which public relations operates and the views of the public relations tasks in the literature are presented. Next, the method of an interview study that explores the tasks of public relations professionals in practice is described. Last, the findings are reported and conclusions drawn. 


\section{Uncertainty of Organizations and Decision Making}

Originally Weick (1979) suggested that organizations do not just interact with their environments but rather enact them. He also (2000) suggested that organizations are a collection of people, whose task is to make sense of what is happening around them. They are unique social forms that embody choice, visibility, and irrevocability. An organization is a system that adapts and sustains itself by reducing the uncertainty it faces every day (Luhmann, 1995). The most common problem that organizations face is how to proceed under uncertainty and make effective decisions (White and Mazur, 1995). Hambrick (1981) stated that coping with uncertainty is the basis for demonstrating the value of public relations. Public relations professionals are members of the organization and serve as boundary spanners (Aldrich and Herker, 1977) and enact with their environment through interaction and meaning creation. Their daily work can be seen as organizing, which helps to reduce the uncertainty that organizational members face when they are making decisions that enable an organization to survive and succeed. Public relations professionals can be seen as sensemakers (Berger and Meng, 2014), as they monitor and interpret the world around the organization.

As Weick (2000) put it, sensemakers convert the world around an organization into an intelligible world and try to make it comprehensible in the best way they can. Weick, Sutcliffe and Obstfeld (2005) emphasized that sensemaking is also clarifying for organizational members how things become an event and what it means for the organization. However, it is important to point out that an indefinite number of possible scenarios can be constructed. This also underlines the problems of active sensemaking: the environment around the organization keeps changing. Weick (2000) proposed that active communicative interaction invokes organizational macro structures and is, as Falkheimer and Heide (2014) argued, a process of constructing and maintaining an organization.

Weick (2000, p. 185) suggested that sensemaking is eventually tied to an individual's activities and to "what the person does is what he eventually knows". The data one collects is, according to Weick (2000), transformed into information in two phases, which were originally developed by Piaget (1962). In this process of transformation, the undifferentiated flow from an organizational environment is first turned into information and broken up as a collection of events. In the second phase, the information and collection of events are transformed into "a network of causal sequences" (Weick, 2000, p. 185-186). The enactment is finalized in a causal map (Weick, 1975), i.e. a perspective into how the events are causally related. Weick concludes that the data transformation into information results in an enacted environment, in other words in self-validated knowledge of the environment of an organization.

Communication in organizations is a form of behavior (Luthans, 1989). Baskin and Arnoff (1988) argued that all behavior is at least potentially communicative and can, therefore, be examined through systems theory. They pointed out that "systems theory applies directly and appropriately to communication" (ibid, 55). The transfer of information allows systems to work and interact with their environments (Katz and Kahn, 1978; Baskin and Aronoff, 1988; Weick, 1995; Luhmann, 2005) by gathering information and interpreting it. The systems approach is applicable to public relations as well because the environment where public relations operates includes political, cultural, social and economic dimensions as Baskin and Aronoff (1988) argued. Public relations includes individual professionals, the organization they work in and the interactions between the public and organizations the professionals strive to influence.

Baskin and Aronoff (1988, p. 60) pointed out that the "communication within an organization is influenced by information and messages that originate in the organization's environment". Furthermore, how the communication system of an organization is working has a great impact on the actions and decision of the organization.

Public relations professionals' work to contribute to organizational decision making can be considered as a strategic action. Verhoeven, Zerfass and Tench (2011) defined strategic communication as a form of strategic action and public relations professionals take the actors inside and outside the organization as the starting point of communication. They emphasize that public relations roles in decision making enable them to act strategically and link communication to organizational objectives. Verhoeven et al. (2011, p. 100) pointed out that "it is important that strategic communication professionals help to define business strategies of the organization and support business goals by planning and executing communication activities." They also emphasized that evaluating and controlling the effectiveness of communication are also part of this strategic orientation of public relations.

The added value of communication to decision making, as Van Lier (2013) argued, is the understanding of communication and the informative value of the content. He emphasized that systems, e.g. organizations, benefit internally from new information when meanings are assigned to information through sensemaking. The problem organizations face is that too much information is available. Van Lier (2013) concluded that the selectivity of information is part of the communication process of systems.

\section{Public Relations in Strategic Decision Making}

In organizations, strategic decision making occurs at enterprise, corporate, business and functional level (e.g. Steyn, 2007; Arcos, 2015). At all these levels, in order to contribute to strategic decision making, public relations needs to be actively involved in the communication that relates to the decision-making process. Public relations professionals, as Huebner, Varey and Wood (2008) suggested, need to establish communicating as an effective management process, rather than apply it just as a supporting process to inform about decisions. In the latter way, as Huebner et al. (2008) added, 
public relations is considered a strategic practice, rather than a management instrument, putting decisions into action. However, public relations can also contribute to decision making in different ways. Ruth-McSwain (2011) argued that public relations possesses decision-making authority throughout the organizational gatekeeping process. At its best, public relations interprets the information with respect to the consequences for organizational strategies and feeds intelligence into the organizational strategy and decision making (Steyn, 2007; Wakefield, 2009).

Brunsson (1982) defined strategic decision making as part of organizational discourse and communication. Later Hendry (2000, p. 964) suggested that in organizations decisions are always manifested in discourse: "the decision which matters is that which is communicated". Although public relations is considered a valuable partner in decision making, as Kanihan et al. (2013) argued, communication professionals are often still not positioned in a way that would allow them to serve the problem-solving purpose effectively. Neill (2013) found that public relations is often competing with marketing at the $\mathrm{C}$ suite level and communication professionals might be included in decision making when the issues are considered to be in their domain. In the European context, as Verhoeven et al. (2011) argued, public relations professionals have developed a "thought structure that links communication to decision making and strategic planning in organizations" (p. 95-96).

The academic discussion on how public relations professionals contribute to organizational decision making has traditionally focused on the public relations roles. The studies on the roles have focused mostly on US practitioners. Moss et al. (2000) argued that the experience US professionals possess may not necessarily be presented similarly in other countries. There is also a significant lack of ethnographic studies of public relations professionals (L'Etang, 2006). Verhoeven et al. (2011) examined the strategic contribution of public relations professionals in a European context. They found that the majority of public relations professionals in Europe contribute to the goals of an organization and to the realization of these goals with communication plans and diverse activities. Much of this work is related to making decision-making processes visible, as Nassehi (2005) argued. Edwards (2009) highlighted that still more studies should focus on the day-to-day lives and the individual level of the public relations activity of professionals.

During the last two decades scholars, such as Leichty and Springston (1996), Porter and Sallot (2003), Moss et al. (2005), Choi (2007) Fieseler, Luzt and Meckel (2015), Johansson and Larsson (2015) and Mykkänen and Vos (2015), have argued that more information is needed to understand public relations professionals' tasks during decision-making processes.

Grunig (2006) argued that public relations and its expertise is needed to scan the environment of an organization as different coalitions are formed for different decisions. In this way the organization gets more possibilities for e.g. ethical decision making. Grunig (2006) also pointed out that public relations professionals need tools that can be used to show the management what (kind of) reactions strategic publics might have when different decisions were made.

Originally, Dozier and Broom (1995) discussed that public relations professionals who concentrate more on the technical tasks as technicians might still have tactical decision-making power in producing and distributing public relations communications. They argued that public relations practitioners produce and distribute the communications independently. Dozier and Broom (1995) also pointed out that if the important management function of public relations is reduced to the technical tasks of producing communications to implement decisions made by others in the organization, the management function of public relations is not performed.

More recently Fieseler et al. (2015) and Niskala and Hurme (2014) examined the tasks of public relations managers in a Nordic context. Fieseler et al. (2015, p. 77) pointed out that "it is important to reconsider the managerial task components as they are often obscured by the manager vs technician debate and because the profession is still constantly redefining its place in many organizations". Their quantitative research revealed that in the Western European context, public relations practitioners wield a large variety of different tasks. They divided their findings into four categories, which they later classified as roles: Diagnosis is about helping circulate information and stakeholder demands. Coaching shows alternative approaches to management for solving communication problems and encouraging management participation. Liaison factor covers activities e.g. maintaining media contacts and producing communication content. Execution factor is responsible for identifying communication problems and acting upon them.

Johansson and Larsson (2015) stated that in organizations, public relations professionals are expected to have a wider scale of duties than many other professional groups. Niskala and Hurme (2014) found public relations professionals to perceive their own tasks and objectives to be more oriented towards society by disseminating information and managing relationships with the key stakeholders. They also argued that public relations professionals identify their tasks primarily related to bond- and trust-building, contributing to the financial and political goals of an organization, and upholding transparency with the social environment of an organization.

\section{METHODOLOGY}

This study aims to create a better understanding of what the contributing tasks of public relations professionals are in organizational decision making in Finland. A qualitative method was chosen because a rich description of the phenomena based on the interviewees' experience was sought. As Daymon and Holloway (2002) argued, this method provides meaningful information based on people's point of view and experiences. Interviews can give information from the past and present, and enable the interviewer to better understand the perspectives of the interviewees, which may 
reveal new phenomena (Keyton 2006).

\section{Research Question}

The research question is as follows: How do Finnish public relations professionals see their tasks in contributing to organizational decision making?

The focus was on clarifying the different kinds of tasks related to organizational decision-making processes.

\section{Data and Analysis}

The data used in this paper has been extracted from a larger dataset that was collected to provide a presentative insight of public relations professionals' contribution to organizational decision making (see Mykkänen and Vos, 2015). The research data for the study was collected during the time period from December 2013 to May 2014 by interviewing 12 public relations practitioners. Overall 19 participants mainly from the central and southern part of Finland were invited to participate in thematic semi-structured interviews. Before the interviews, the final interview protocol was critically reviewed by one independent public relations professional and one experienced scholar.

Participation in the interviews was based on availability and willingness. The participants mostly worked in the role of a communication manager or a director, as nine managers out of 13 expressed their willingness to participate. In addition, six senior press officers were asked to participate, three of whom expressed their availability for the study. Overall 12 public relations professionals from different organizations were interviewed. Six organizations were from the private sector, five from the public sector, and one was a non-governmental organization.

Anonymity and confidentiality were promised and ensured to all the participants. Only one interviewee per organization was selected for the interview. Another criterion for the participants was that the organization should have a distinguished public relations function and it should employ at least two public relations professionals. The audio-recorded interviews were conducted in person by the author and they lasted from 30 to 70 minutes. In total, over eight hours of discussions were recorded. The whole content of the conversations was transcribed for further analysis but the different tones of voice, pauses, and filler words were left out. The data contained over 90 pages of transcribed material.

The transcribed data was then transferred to Atlas.ti, a qualitative analysis software for content analysis. The content was analyzed based on the order of the questions in the questionnaire. The interviewees' quotations were coded according to the questions asked. The codes were divided into main code families for professionals' roles, tasks and capabilities related to decision making. In this paper, the data of codes regarding tasks is presented (see also Mykkänen and Vos, 2015).

Every task mentioned in the interviews was recorded and described. Then their description was checked against an encyclopedia, and practical combinations for the tasks were made. Finally, all the tasks were critically analyzed and merged into nine final categories. In the next chapter, the findings are presented. The findings of this study are based on the content of the interviewees' quotations.

\section{Background Information}

All the participants were asked to fill in a background information form at the beginning of the interview. In this form, they described their position as a public relations professional. From the 12 participants, four were males and eight were females. The reported average work experience in the field of organizational communication was 13.8 years. The public relations departments in which the interviewees worked ranged from 2 to 14 employees in size. Their organizations also varied in size, from just 40 to 27000 employees.

All the participants reported that public relations professionals were invited to board meetings; in three organizations, this concerned public relations together with marketing experts. Six interviewees stated that their organization has multiple boards and that public relations professionals are invited to all of them. One interviewee (of a large organization), however, reported that public relations professionals were invited to the boards at all levels except the top board.

Four interviewees reported public relations to have advisory power in the board, including the right to attend and express opinions. Eight participants reported having voting power, which indicates full membership of the board. The participants also reported public relations to be invited into various organizational sub-boards, in which they may have various kinds of privileges and power. This indicates that, in practice, public relations practitioners may have diverse tasks and responsibilities in organizational decision making.

\section{FINDINGS}

Tasks in contributing to organizational decision making

One question in the semi-structured interview aimed at bringing out public relations professionals' perceptions of their tasks and duties during organizational decision-making processes. The question was: How do you contribute to decision making in your organization? The interviewees were asked to describe in their own words how they contribute. If needed, the participants were asked to list different tasks contributing to decision-making processes individually. They also were encouraged to add examples.

The participants were encouraged to talk freely about their tasks in organizational decision making. Their answers gave a more complex picture of how they functioned in practice and they did not list just one specific task. In total, 135 mentions of different tasks in contributing to decision making were identified and coded. After this the descriptions that most resembled each other were grouped together into nine categories. Finally, these categories were labelled. Even though this was done with care, the label of categories should be read together with their descriptions (see Table I) 
Table I: The Task Categories of Public Relations Professionals in Contributing to Decision making.

\begin{tabular}{|c|c|c|}
\hline Total & Task & Summary \\
\hline 21 & Dissemination & $\begin{array}{l}\text { Disseminating, writing and publishing information about a decision-making process } \\
\text { and/or decisions using various communication channels. Communicating with the } \\
\text { media about the decision-making process and the outcomes of decisions. }\end{array}$ \\
\hline 20 & Coordination & $\begin{array}{l}\text { Coordinating and managing the actions and content about decision making with other } \\
\text { public relations professionals and the board. Coordinating the role of the public } \\
\text { relations function in decision-making processes, e.g. by managing core messages as } \\
\text { well as guiding the discussion within an organization. Contributing to the decision- } \\
\text { making process by producing and managing the information in electronic databases } \\
\text { and virtual working spaces. }\end{array}$ \\
\hline 18 & Dialogue & $\begin{array}{l}\text { Promoting two-way communication in decision-making processes by arranging } \\
\text { dialogue with stakeholders, and pointing out the communicative dimensions, issues } \\
\text { and the flow of information. Promoting the openness of decision making by creating } \\
\text { a more communicative environment by contributing to discussion, document sharing, } \\
\text { and collaborative communication tools. }\end{array}$ \\
\hline 18 & Implementation & $\begin{array}{l}\text { Implementing decisions by communicating, arranging meetings, clarifying the focus } \\
\text { and facts of decisions and supporting the superior-subordinate level communication. } \\
\text { Operationalizing the decisions and implementing change by creating timetables and } \\
\text { materials, the form of messages, suitable channels and appropriate communicative } \\
\text { actions. }\end{array}$ \\
\hline 14 & Research & $\begin{array}{l}\text { Monitoring of stakeholder views and identifying issues around decision-making } \\
\text { processes. Thinking, evaluating, analyzing and reporting on behalf of and to the } \\
\text { board of the pros and cons of decision-making process as well as the aspects of the } \\
\text { communicative actions of decisions. }\end{array}$ \\
\hline 13 & Consulting & $\begin{array}{l}\text { Consulting, advising, sparring and preparing material for the management and for the } \\
\text { board with cooperation to promote decision-making processes. }\end{array}$ \\
\hline 12 & Participation & $\begin{array}{l}\text { Participating in board meetings at different levels to ensure the access to information } \\
\text { and to influence the decision-making process through strategy and vision creation. } \\
\text { Participating in various meetings within the organization to contribute to the } \\
\text { communication process of superiors about decisions and to ensure access to relevant } \\
\text { information. To participate in a public or an online event with stakeholders to discuss } \\
\text { the decision-making process and/or decisions. }\end{array}$ \\
\hline 11 & Planning & $\begin{array}{l}\text { Planning and developing internal and external communication processes to bring } \\
\text { strategic decision making to the operational level. }\end{array}$ \\
\hline 8 & Contextualizing & $\begin{array}{l}\text { Clarifying the core elements in the topic, building a proper communicative context } \\
\text { around the facts, and forming the appropriate tone of communication about decision- } \\
\text { making processes for daily operations of the organization. }\end{array}$ \\
\hline 135 & Overall & \\
\hline
\end{tabular}

In the following subsections, these categories of tasks are presented more closely with the descriptions provided by the interviewees. Generally, the interviews indicated that the idea of the tasks related to the contribution of public relations to organizational decision making was rather novel to many of the public relations professionals interviewed. The interviewees acknowledged that they were expected to contribute to organizational decision making. When asked about their tasks in the decision-making process, not all the interviewees were prepared to point this out and explain how they contributed to decision making in practice.

\section{Dissemination}

In this category, six different tasks related to dissemination were mentioned 21 times in total. Informing (11 mentions during the interviews) was described as one-way communication to stakeholders. Public relations professionals inform about decisions, the decision-making process or the possibilities for stakeholders to give feedback and influence the process. Public relations also informs how the (press) meeting went, how the decision-making process has been executed and how the decision is justified. Media communication (4 mentions) task is mainly communication with the media about the outcomes of decisions. It is about communicating the negative decisions as well and it is much about telling a story by using the media to influence the internal stakeholders of the organization. Communication (magazine) (3 mentions), was described to be related to writing and publishing a customer magazine. The magazine opens and explains the background of decisions and what they mean for stakeholders. The magazine also opens up the main strategy of the organization. Spinning (1 mention) is related to media communication and it is very much the normal spinning routine of public relations to get some media coverage for the decisions. Financial communication (1 mention) is clearly related to the one-way communication about (?) decisions that have a financial impact on the organization. Communication (web) (1 mention) was described to be related to communication on social media and official websites.

\section{Coordination}

Coordination (5 mentions) is linked either to managing the 
whole work concerning the decision-making process with the help of the public relations function or to the cooperative work with business units. In the first case, the responsible public relations manager coordinates the annual work of individual public relations employees. The manager "solves the puzzle", creates the core messages related to the topic discussed, narrows down themes, and unifies and combines themes for one big entity. The most crucial thing is to narrow down tasks to keep the entity doable for public relations function. In the latter task / case, the public relations manager coordinates the discussions with business units on how the outcomes of a decision could be contributed to in practice. This means creating a communication plan either for one business unit or for the whole organization. This also includes evaluating the themes and possibilities for communication. Intranet (4 mentions) as a task contributes to the decision-making process recognizing the role of the intranet as part of the supportive channels for the decision-making process. It is the responsibility of public relations to create content on the intranet regarding the decision-making process and the outcomes of decisions. An intranet is considered to promote the decision and to give information about the process and the outcomes. In addition, different notifications in electronic form, like email notifications and group mailings, were mentioned. Electronic tools (3 mentions) is related to the various electronic tools public relations uses in communication. This includes collaboration tools and virtual working spaces where documents can be shared and comment. Guiding communications ( 2 mentions) is related to keeping the big picture of communication clear and the red thread of communication focused. Public relations plans what communicative actions are feasible. Management (2 mentions) is related to the overall management of daily work. In communication function, a/the communication manager must maintain the big picture and ensure that other employees in public relations have possibilities as is wanted and that the agreed actions are made. This also includes proceeding with a given role in the board ensuring that public relations representatives are managing the tasks which they are given. Content management ( 2 mentions) is related to the work of communication managers. Their task is to manage what content is included when communicating about decisions. The term mutual discussions ( 1 mention) was described to include discussions with colleagues about the communication plan for the next year.

\section{Dialogue}

Promotion of two-way communication (10 mentions) was identified as the promotion of communications related to decision-making processes. Public relations professionals actively try to bring more communicative methods to decision making by explaining how they could help in the decisionmaking process, what the possibilities for dialogue are, what communicative dimensions the decision might have, how this could affect stakeholders, how the goal is achieved, and what internal and external issues it might have. Conversation creating (3 mentions) is related to creating a more communicative environment around decisions by promoting discussion. This is created by giving possibilities to discuss face to face or online in public events, creating collaborative communication tools, sharing documents and creating discussion on the intranet. Transparency promotion (3 mentions) is related to the willingness of public relations to promote the openness and transparency of the decisionmaking process if possible. This could be for instance not hiding the negative news of the organization when laying off workforce or "telling the story first". This is also giving opportunities for discussion face to face or via digital tools. Campaigning (2 mentions) is more related to marketing communication, and contributes to the decisions through the methods of marketing, e.g. direct letter postings, and email campaigning.

\section{Implementation}

Internal communication (7 mentions) was identified to contain the traditional internal communication about decisions and decision-making processes to employees. The interviewees found that it contains writing and managing the news on the intranet, making press releases, overall communication about themes that are discussed in the board(s), arranging internal meetings, and telling employees what expectations decisions create for them. Public relations also contributes to the superior-subordinate communication, tries to keep the whole personnel informed, clarifies the top-level focus of decision making, produces reasoning for decision outcomes, and gives the facts about what will be done in the future and about what the goals are. Operationalization ( 5 mentions) is found to be, to a great extent, traditional operative communication. Public relations is regarded as a function which is responsible for the operative implementation of decisions by deciding the timetable of communication, the form of the messages and the channel for communication. At the manager level, operationalizing is also the execution of timed communication actions. Material production (3 mentions) includes the production of material which is related to a decision and which needs to be discussed. Materials are very concrete, e.g. brochures, letters, visual materials and videos. Supporting (2 mentions) is related to supporting the daily operations of an organization by giving ideas for business units on how to get the messages through. This is also related to superiorsubordinate communication, so the employees are wellinformed about the goals of the organization. Change promotion ( 1 mention) is related to promoting the change after a decision. The quotation on change promotion also includes the terms discussion creation and openness, so this should perhaps be combined with the transparency creation or creating discussion.

\section{Research}

Analyzing (5 mentions) was found to contain thinking and evaluating what communication actions should be made, how things should be promoted, what pros and cons the matter would have, what pitfalls it might have, what issues might harm the organization and why this kind of reform should be made. This was found to be part of daily work and public relations professionals consider what themes should be communicated so that messages would flow through them. On the operational side, they also think of what should be done for instance regarding their customer magazine. Impact evaluation (3 mentions) means that public relations as a function evaluates and communicates the result of the evaluation to the board. The evaluation includes aspects of how stakeholders are affected by the decision, what different dimensions the decision might have, and how the communication with stakeholders is affected. This task is also used to evaluate if the media is interested in this topic and if the organization should be proactive with this topic. Gathering feedback ( 2 mentions) is related to ensuring that it is possible to gather feedback via electronic channels or discussions. Background work ( 2 mentions) is more about collecting information, backgrounds and getting ready to explain things to the board. Monitoring (1 mention) is related to monitoring 
and identifying different things and issues that are related to the performance of the organization. Reporting ( 1 mention) is related to the creation of summaries that are assigned to be sent to the board.

\section{Consulting}

This category contains seven different tasks. Expertise (4 mentions) is related to how public relations function is bringing their own expertise and substance into the decisionmaking table and how they promote it in decision-making processes. This also includes, according to quotations, giving pieces of advice and sparring the top management between decisions. Expertise is related to situations where there is not much time to react and public relations has to make quick communicative actions. In these cases, the trust upon public relations is tested. Private discussions ( 3 mentions) are a very intimate way to contribute to the decision-making process and they support the ideas of a decision maker. The public relations professional advises the dominant coalition from the communicative point of view. Consulting ( 2 mentions) is related to the board or the CEO and refers to consulting them through frequent mutual communication on how public relations can contribute to the decision and on what possibilities the decision opens for communication and for the organization to start discussing the topic. Inspiring (1 mention) was described to refer to creating "good mood" for superiors to give them some boost. Sparring (1 mention) is related to how public relations professionals express their opinions in a group where strategically important things are discussed. This also contains the idea that public relations should have a role in the strategy creation process. Preparing (1 mention) is related to preparing the communication material of board decisions, for instance press releases, together with other public relations professionals. Cooperation ( 1 mention) is cooperating with the CEO on communicative aspects.

\section{Participation}

Board meeting participation (4 mentions) is related to the general participation in decision making. Public relations is entitled to or must participate in different boards and other lower level meetings to ensure, that they'll get the information they need and that they have the possibility to influence the decision-making process. Without being present in the meetings, the public relations have no possibilities to influence or even be part of the decision-making group. Being present gives them a better chance to have a role in decision making. Internal participation (3 mentions) is related to the participation in the decision-making process. Public relations wants to participate to be close the sources of information and to the operations where the daily work is done. Public relations sits in meetings with employees and superiors, discusses internal and external possibilities with production units and defines the ways of how to contribute to their work. Public participation (3 mentions) is related to traditional work where public relations professionals participate in public meetings /events either face to face with the media or with other stakeholders, or in online events. Public relations participates in collecting feedback or in ensuring that stakeholders have a possibility to discuss the decision and public relations can also promote its point of view. Decision content creation ( 1 mention) is related to the creation process of strategy and vision. According to the quotation, public relations has a major role when creating the content for the new strategy and vision. Strategy creation (1 mention) was described to be involved in strategy creation and public relations is giving input from the communication point of view.

\section{Planning}

Planning (9 mentions) was mentioned and identified to be about planning how a decision is operationalized. In this task, public relations plans what communicative actions are made, what the timetable for them is, how feedback is collected, what themes are used, and what point of views are used in different occasions. In addition, public relations decides what is told in the press releases, how the media is contacted and what wishes business units have and how these are taken into consideration, what different individual public relations employees are doing, and how the decision is justified. Development (2 mentions) is related to developing the communication plans of public relations. This contains the timetable and the communicative actions which are related to the decisions about the operation plan in the organization. Public relations could also be part of developing the strategy.

\section{Contextualizing}

Contextualizing (4 mentions) is related to creating the right context for messages. Public relations is asked or they are willingly creating the suitable communicative context for the messages about decisions so they can be tied into the daily operations of the organization. This includes what information is included in the communication and what kind of tone is used in the communication. This also contains the reasoning and the facts that the board wants, in addition to the plans on what should be done in the future. Creation of understanding (3 mentions) is making the decision understandable by clarifying the message, i.e. what it means for the daily operations of organizations, what it means for the communication function as a whole and what the board really wants to say so the whole organization understands. Meaning creation ( 1 mention) is related to the management work where the communication manager decides the tone of communication and how the message will be formed.

\section{CONCLUSIONS AND DISCUSSION}

The various task categories formed based on the interviews are brought together in a new overview. Figure I shows the nine identified task categories. Short summaries of each task category are presented under the figure.

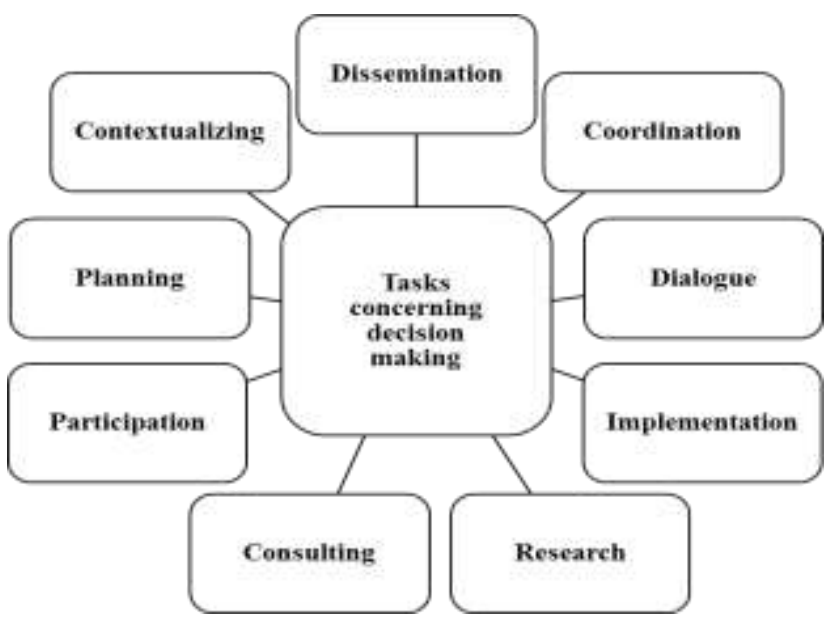

Figure I: The Contribution Model of Public Relations Professionals to Organizational Decision Making.

The first and the most acknowledged task category, dissemination, includes various ways to communicate information about a decision-making process and decisions 
via different communication channels. Coordination includes the coordination and management of the actions and the related content of organizational communication about decisions. Promotion consists of promoting several communicative aspects of decision-making processes and pointing out possible issues. Implementation refers to operationalizing the decisions and implementing change by creating various organizational routines, for instance timetables and materials, together with appropriate communicative actions. Research includes the monitoring, analyzing, evaluation and reporting responsibilities related to decision making. Consulting comprises advising, sparring and consultation of the management and cooperation with the board during decision-making processes. Participation in decision making focuses on active participation in board meetings on various levels to ensure the access to and the input of information and the influence on the decision-making process. Planning involves bringing the internal and external communication processes related to strategic decision making to the operational level. Contextualizing implicates the clarification and building of a proper communicative context around the facts related to a decision-making process.

The initial results of this research show that public relations professionals contribute to organizational decision-making processes through many different tasks. The interviewees described their contribution in various ways, resulting in 135 quotations delivered during the interviews. After the analysis, these quotations were divided into nine distinguished task categories. The most frequent task category in decisionmaking processes was related to the dissemination of decisions with 21 mentions. After this the most often mentioned task categories were coordination, promotion and implementation (Table I). An analysis of different tasks indicates that the way in which public relations professionals contribute to decision making varies according to the different phases of decision making. The interviewees expressed to have multiple (simultaneous) tasks during the decisionmaking processes.

The results of this study uphold Grunig's (2006) findings that participation in top level management means different things to public relations professionals. Grunig (2006) also proposed to conduct further research on how public relations can be institutionalized as a bridging activity more broadly in organizations. The findings of this study show that the tasks of public relations discussed here contain important elements included in decision-making processes and hence support the bridging activity of public relations. This braces the argument of White and Mazur (1995) that public relations can contribute to the decision making of the management in uncertain conditions. This way public relations could also bridge itself more into the top level management and institutionalize itself more as a strategic partner. The results of this study underline how public relations as a function and through its processes can create a unique contribution to organizational decision making. This way public relations could, even more, fulfil their role as strategic management as Grunig (2006) encouraged to explore. The findings support also Leichty and Springston's (1996) argument that a lot of information is lost if practitioners' tasks are only considered from either the manager's or the technician's point of view. The overall findings also brace the findings of Johansson and Larsson (2015) that public relations in organizations has a service, support, and advisory function.

Theory wise, it would be important to study what kind of impact the empirical research in different organizational settings and contexts would have. As Nassehi (2005, p. 15) pointed out, "the desideratum of Luhmann's organization theory is to describe in more detail how special kind of order of organizations is related to interactional and societal levels". The contribution of this paper was to describe how public relations professionals interact in their organizational settings and contexts during decision-making processes.

This small exploratory study gives insight into the organizational decision making and the tasks of public relations professionals in the Finnish organizational context. The data provides some interesting findings on the daily work of public relations professionals. As this was a qualitative study, the verification of results and the proposed model needs further quantitative research. The interviewees' answers were translated from Finnish to English and it has to be noted that this might have affected the results. To further complement the contribution of public relations professionals to organizational decision making, it would be beneficial to also examine the needed skills and competencies of public relations professionals that enable a strong contribution to organizational decision making.

\section{References}

Aldrich, H. \& Herker, D. (1977). Boundary spanning roles and organization structure. Academy of Management Review, 2 (2), 217-230.

Arcos, R. (2016). Public relations strategic intelligence: Intelligence analysis, communication and influence. Public Relations Review, 42 (2), 264-270.

Baskin, O. \& Aronoff, C. (1988). Public Relations: The Profession and the Practice. 2nd ed., W.C. Brown, Dubuque, Iowa.

Berger, B.K. \& Meng, J. (2014). Public Relations Leaders as Sensemakers: A Global Study of Leadership in Public Relations and Communication Management. Routledge.

Brunsson, N. (1982). The irrationality of action and action rationality: decisions, ideologies and organizational actions. Journal of Management Studies, 19 (1), 29-44.

Cheney, G., Christensen, L., Zorn, T., \& Ganesh, S. (2004). Organizational Communication in an Age of Globalization: Issues, Reflections, Practices. Prospect Heights, Ill: Waveland Press, cop.

Choi, J. (2007). Elaborating the concept of public relations role and a test of its utility, doctoral dissertation. UMI No. 3298030, ProQuest Dissertations and Theses database, Michigan State University, East Lansing, MI.

Cutlip, S., Center, A., \& Broom, G. (2006). Effective Public Relations (9th ed.). UpperSaddle, NJ: Pearson Prentice Hall.

Daymon, C. \& Holloway, I. (2002). Qualitative Research Methods in Public Relations and Marketing Communication. London. Routledge.

Falkheimer, J. \& Heide, M. (2014). From public relations to strategic communication in sweden: The emergence of a transboundary field of knowledge. Nordicom Review, 35 (2), $123-138$

Fawkes, J. (2004). What is public relations? In Theaker, A. The Public Relations Handbook. Routledge.

Fieseler, C., Lutz, C. \& Meckel, M. (2015). An inquiry into the transformation of the PR roles' concept. Corporate Communications: An International Journal, 20 (1), 76-89. 
Dozier, D. M. (1989, May). Importance of the concept of symmetry and its presence in public relations practice. Paper presented at the meeting of the Public Relations Interest Group, International Communication Association, San Francisco.

Dozier, D.M. \& Broom, G.M. (1995). Evolution of the manager role in public relations practice. Journal of Public Relations Research, 7 (1), 3-26.

Edwards, L. (2009). Symbolic power and public relations practice: locating individual practitioners in their social context. Journal of Public Relations Research, 21 (3), 251272 .

Grunig, J. (2006). Furnishing the Edifice: Ongoing Research on Public Relations as a Strategic Management Function., Journal of Public Relations Research, 18 (2), 151-176.

Hambrick, D.C. (1981). Environment, strategy, and power within top management teams. Administrative Science Quarterly, 26, 253-276.

Hendry, J. (2000). Strategic decision making, discourse, and strategy as social practice. Journal of Management Studies, 37 (7), 955-977.

Huebner, H., Varey, R. \& Wood, L. (2008). The significance of communicating in enacting decisions. Journal of Communication Management, 12 (3), 204-223.

Johansson, B. \& Larsson, L. (2015), The complexity of public relations work. PR managers in the public and private sector in Sweden. Nordicom Review 36, 125-139.

Kanihan, S., Hansen, K.A., Blair, S., Shore, M. \& Myers, J. (2013). Communication managers in the dominant coalition: power attributes and communication practices. Journal of Communication Management, 17 (2), 140-156.

Katz, D. \& Kahn, R. (1978). The Social Psychology of Organizations. New York: Wiley.

Keyton, J. (2006). Communication Research: Asking Questions, Finding Answers. 2nd edition. McGraw-Hill Higher Education, Boston, Mass.

L'Etang, J. (2006). Public relations and propaganda: Conceptual issues, methodological problems and public relations discourse. In J. L'Etang and M. Pieczka (Eds.). Public relations: Critical debates and contemporary practice (pp. 23-40). Lawrence Erlbaum Associates. Mahwah, NJ.

Leichty, G. \& Springston, J. (1996). Elaborating public relations roles. Journalism and Mass Communication Quarterly, 73 (2), 467-477.

Luhmann, N. (1995). Social Systems. Stanford, Calif.: Stanford University Press.

Luthans, F. (1989). Organizational Behavior. Singapore, McGraw Hill.

Moss, D., Newman, A. \& DeSanto, B. (2005). What do communication managers do? Defining and refining the core elements of management in a public relations/ corporate communication context. Journalism and Mass Communication Quarterly, 82 (4), 873-890.

Moss, D. \& Green, R. (2001). Re-examining the manager's role in public relations: what management and public relations research teaches us. Journal of Communication Management, $6(2), 118-132$.
Mykkänen, M. \& Vos, M. (2015). The contribution of public relations to organizational decision making: insights from the literature", Public Relations Journal, 9 (2).

Nassehi, A. (2005). Organizations as decision machines: Niklas Luhmann's theory of organized social systems. The Sociological Review, 53(1), 178-191.

Niskala, N. \& Hurme, P. (2014). The other stance. Conflicting professional self-images and perceptions of the other profession among Finnish PR professionals and journalists. Nordicom Review 35, 105-121.

Neill, M. (2015). Beyond the c-suite: corporate communications' power and influence. Journal of Communication Management, 19, (2) 118-132.

Pace, R.W. \& Faules, D.F. (1994). Organizational Communication. Englewood Cliffs, N.J: Prentice Hall.

Porter, L.V. \& Sallot, L.M. (2003). The internet and public relations: Investigating practitioners' roles and world wide web use. Journalism and Mass Communication Quarterly, 80 (3), 603-622.

PRSA (1982). Official Statement on Public Relations. http://www.prsa.org/aboutprsa/publicrelationsdefined/docume nts/official\%20statement\%20on\%20public\%20relations.pdf. Retrieved 07.06.2016.

Ruth-McSwain, A. (2011). Gatekeeper or peacekeeper: the decision-making authority of public relations practitioners. Public Relations Journal, 5 (1).

Steyn. B. (2007). Contribution of public relations to organizational strategy formulation. In E. L. Toth (Ed.), The future of excellence in public relations and communication management: Challenges for the next generation. (pp. 137172). Mahwah, NJ: Lawrence Erlbaum

Van Lier, B. (2013). Luhmann meets Weick: Information interoperability and situational awareness. Emergence: Complexity and Organization, 15 (1), 71-95.

Van Ruler, B. \& de Lange, R. (2003). Barriers to communication management in the executive suite. Public Relations Review, 29, 145-158.

Verhoeven, P., Zerfass, A. \& Tench, R. (2011). Strategic orientation of communication professionals in Europe. International Journal of Strategic Communication. 5 (2), 95117.

Wakefield, R. (2009). Public Relations Contingencies in a Globalized World Where Even "Glocalization" is Not Sufficient. Public Relations Journal, 3 (4).

Weick, K.E. (1979). The Social Psychology of Organizing. New York: Random House.

Weick, K.E. (1995). Sensemaking in Organizations. Thousand Oaks, Calif.: Sage.

Weick, K.E. (2000). Making Sense of the Organization. New York: Wiley.

Weick, K.E., Sutcliffe, K.M. \& Obstfeld, D. (2005). Organizing and the process of sensemaking. Organization Science, 16 (4), 409-421.

White, J. \& Mazur, L. (1995). Strategic Communications Management: Making Public Relations Work. Wokingham: Addison-Wesley. 